\title{
Fluorescence Measurement of Changes in Intracellular Calcium Induced by Excitatory Amino Acids in Cultured Cortical Astrocytes
}

\author{
A. M. Jensen ${ }^{2}$ and S. Y. Chiu ${ }^{1}$ \\ 'Department of Neurophysiology and ${ }^{2}$ Neuroscience Training Program, University of Wisconsin, Madison, Wisconsin 53706
}

\begin{abstract}
Population response of $\left[\mathrm{Ca}^{2+}\right]_{1}$ in cultured cortical astrocytes to excitatory amino acids was measured at room temperature using the calcium-sensitive dye fura-2. Quisqualic acid (QA), glutamate (Glu), and kainic acid (KA) caused a peak increase in $\left[\mathrm{Ca}^{2+}\right]_{i}$ in the order QA $>\mathrm{Glu}>\mathrm{KA}$. No response to N-methyl-D-aspartic acid (NMDA) was observed whether or not $\mathrm{Mg}^{2+}$ was present externally. Both QA and Glu (100 $\mu \mathrm{M})$ trequently elicited a decaying oscillatory $\left[\mathrm{Ca}^{2+}\right]_{i}$ response during sustained agonist application; the period of oscillations initially was $23.5 \mathrm{sec}$ and increased as the response was damped. Comparatively, the $\left[\mathrm{Ca}^{2+}\right]_{\text {, response to }}$ KA was nonoscillatory. Both responses to Glu and KA were reduced slightly by antagonist $\gamma$-D-glutamylaminomethylsulfonic acid ( $1 \mathrm{~mm}$ ), but virtually were abolished by kynurenic acid (3 mM). Replacement of external $\mathrm{Na}^{+}$by choline had no significant effect on the Glu response. Removal of external $\mathrm{Ca}^{2+}$ reduced the peak response to QA, Glu, and KA to 40,34 , and $18 \%$, respectively; and markedly reduced the degree of QA- and Glu-induced $\left[\mathrm{Ca}^{2+}\right]_{i}$ oscillations. Pretreatment with phorbol esters, a potent activator of protein kinase $\mathrm{C}$, blocked the $\left[\mathrm{Ca}^{2+}\right]_{i}$ response to Glu but not $\mathrm{KA}$. It is concluded that cortical astrocytes express Glu receptors of the non-NMDA type in culture and that receptor activation leads to $\mathrm{Ca}^{2+}$ influx and release of internal $\mathrm{Ca}^{2+}$. Mobilization of $\mathrm{Ca}^{2+}$ apparently occurs via the known Glu-mediated hydrolysis of inositol lipids, which may come under negative-feedback control by protein kinase $\mathrm{C}$ activation. Oscillatory $\left[\mathrm{Ca}^{2+}\right]_{\mathrm{i}}$ signaling offers the possibility of a dynamic population response in an electrically coupled glial network.
\end{abstract}

Even though neurons are the key cell types for active signaling in mammalian CNS, they constitute a relatively minor cellular component compared with glial cells, which have been estimated to make up about one-half of the volume of brain, and by nuclei counts outnumber neurons 10:1 (Kuffler et al., 1984). Astrocytes are by far the most abundant type of glia. These cclls are distinguished by different cell lineage (Raff, 1989) and diverse cell-cell relations. Astrocytes maintain close contacts with

\footnotetext{
Received Sept. 19, 1989; revised Oct. 23, 1989; accepted Oct. 25, 1989.

We wish to thank Dr. Etty Benveniste for help in astrocyte cultures, Lisa Hendrickson and Mary Halloran for assistance in immunocytochemistry, and Carol Dizack and Terry Stewart for help in illustration and photography. This work was supported in part by grants NS-23375 from the USPHS, RG-1839 from the U.S. National Multiple Sclerosis Society, and a Pew Scholar award in the Biomedical Sciences to S.Y.C.

Correspondence should be address to S. Y. Chiu, Department of Neurophysiology, University of Wisconsin, 283 Medical Sciences Building, 1300 University Avenue, Madison, WI 53706.

Copyright (C) 1990 Society for Neuroscience $0270-6474 / 90 / 041165-11 \$ 02.00 / 0$
}

blood vasculatures, form gap junctions with other astrocytes (Gutnick et al., 1981), fill the space between neurons, and send fine processes to the node of Ranvier (ffrench-Constant and Raff, 1986; Black and Waxman, 1988). Their close proximity to neurons allows astrocytes to influence passage of information by environment modulation via uptake and clearance of substances released by neurons, among them $\mathrm{K}^{+}$and neurotransmitters (for review, see Schousboe et al., 1988).

The issue of whether astrocytes can participate in active signaling, in which external stimuli are amplified and regenerated as in neurons, has received much attention due to recent findings that membrane proteins mediating neuronal response, like voltage-gated ion channels (MacVicar, 1984; Bevan et al., 1985; Barres et al., 1988) and neurotransmitter receptors are present in cultured astrocytes. Indeed, glutamate (Glu), probably the most widely used neurotransmitter in neuronal transmission, has been found to elicit a variety of electrophysiological and biochemical responses in cultured astrocytes. Glu and related excitatory amino acids have been shown to cause a membrane depolarization (Bowman and Kimclberg, 1984; Kettenmann ct al., 1984; Kettenmann and Schachner, 1985) and, more recently, directly activate ion channels in patch-clamp studies (Usowicz et al., 1989). In biochemical studies, excitatory amino acids have been found to induce breakdown of inositol lipids (for review, see Pearce and Murphy, 1988). Thus, astrocyte membranes not only are involved in uptake processes, but are capable also of active signal transduction via ion flux (voltage and neurotransmitter-gated ion channels) and receptor-mediated generation of second-messenger cascades (IP3 and $\mathrm{Ca}^{2+}$ ) for long- and shortterm cellular modulation. Indeed, the expression of ion channels (Barres et al., 1988) and receptors (Gallo et al., 1989) in astrocytes appears to be dependent on cell lineage and cell phenotype, suggesting a role in the developing brain. Further, the presence of Glu receptors in type-2 astrocytes whose processes are closely apposed to nodes of Ranvier has prompted speculation for some form of axon-to-glia signaling with astrocytes as a recipient of neurotransmitters (Usowicz et al., 1989). In squid giant axons, neurotransmitter mediated axon-to-glia signaling has been demonstrated (Villegas, 1984; Lieberman et al., 1989).

In this study, the $\mathrm{Ca}^{2+}$-sensitive dye fura-2 (Grynkiewicz et al., 1985; Tsien, 1989) was used to measure changes in intracellular $\mathrm{Ca}^{2+}$ in cultured astrocytes induced by excitatory amino acids. Such a sludy is of interest for various reasons. First, $\mathrm{Ca}^{2+}$ mobilization resulting from receptor-mediated hydrolysis of inositol lipids has been studied mostly in flux measurements using ${ }^{45} \mathrm{Ca}^{2+}$ (Lazarewicz and Kanje, 1981; for review, see Pearce and Murphy, 1988). Clearly, a finer kinetic description of $\mathrm{Ca}^{2+}$ signaling only can be obtained through direct measurement of 
$\left[\mathrm{Ca}^{2+}\right]_{i \cdot}$. Second, $\mathrm{Ca}^{2+}$ plays a role in mediating many cellular responses and may be particularly relevant in certain astrocyte functions like neurotransmitter-induced release of neurotransmittcrs (Schousboc ct al., 1988) and mobilization of glycogen stores (Ververken et al., 1982). Further, Glu-induced $\mathrm{Ca}^{2+}$ mobilization via the inositol pathway may play a role in regulation of growth and differentiation in astrocytes (Nicoletti et al., 1988). Third, stringent regulation of $\mathrm{Ca}^{2+}$ is needed in cell systems using this ion for intracellular signaling; prolonged rise in intracellular $\mathrm{Ca}^{2+}$ activates proteolytic enzymes leading to cell death, as has been suggested for Glu-induced overloading of $\mathrm{Ca}^{2+}$ in neurons (for review, see Choi, 1988). Interestingly, excessive Glu exposure is toxic to neurons but not astrocytes (Choi et al., 1987; Cummings et al., 1988), suggesting that astrocytes possess a different, or better, feedback regulation of $\mathrm{Ca}^{2+}$ which protects glia from sustained rise in cytoplasmic calcium. This further would be of particular interest in pathological conditions in which proliferation of astrocytes may make them major targets for Glu.

\section{Materials and Methods}

Materials. Excitatory amino acids [L-glutamic acid (Glu), quisqualic acid (QA), kainic acid (KA), N-methyl-D-aspartic acid (NMDA)] and antagonists [kynurenic acid, $\gamma$-D-glutamylaminomethyl-sulfonic acid (GAMS)] were purchased from Sigma (St. Louis, MO). Active [phorbol 12-myristate 13-acetate (PMA)] and inactive [ $4 \alpha$-phorbol 12,13-didecanoate (PDD)] phorbol ester analogs and pertussis toxin were purchased from Sigma. The corresponding inactive $\alpha$ analog of phorbol 12-myristate 13-acetate ( $\alpha$-PMA) was a gift from Dr. Thomas Martin at the University of Wisconsin, Madison. Ionomycin was purchased from Calbiochem (San Diego, CA). Fura-2 acetoxy-methyl ester (fura2/AM) was purchased from Molecular Probes (Junction City, OR). Tissue culture media and reagents were obtained from Gibco (Grand Island, NY). GFAP staining kit was obtained from Accurate Chemical (Westbury, NY; catalog number BX-HP020-5P).

Cell cultures. Cerebral cortices from postnatal day-2 rats (SpragueDawley) were stripped of the meninges, cut into small pieces, then gently triturated through an 18 gauge syringe needle to yield a cell suspension. The cells were filtered through a $60 \mu \mathrm{m}$ Nitex mesh (Tetko, Elmsford, $\mathrm{NY}$ ), pelleted by gentle centrifugation $(5 \mathrm{~min}, 400 \times \mathrm{g})$, resuspended, and plated onto $75 \mathrm{~cm}^{2}$ T-flasks. Cells were grown to confluence $(\sim 7$ d) in a Dulbecco's modified Eagle's medium containing $10 \%$ fetal bovine serum, insulin $(10 \mu \mathrm{g} / \mathrm{ml})$, L-glutamine $(2 \mathrm{mM})$, transferrin $(10 \mu \mathrm{g} / \mathrm{ml})$, sodium selenite $(60 \mathrm{nM})$, non-essential amino acids $(0.1 \mathrm{~mm})$, and gentamycin $(50 \mathrm{ng} / \mathrm{mll})$. The flasks then were shaken mechanically on a horizontal orbital shaker (Bellco $7744,1.6 \mathrm{~mm}$ orbit, $1000 \mathrm{rpm}$ ) for 6$8 \mathrm{hr}$ at room temperature to remove the top layer of cells which contains oligodendrocytes and presumably type 2 astrocytes (McCarthy and De Vellis, 1980). The remaining cells were trypsinized and replated at a lower density and, after $1 \mathrm{~d}$, were treated with cytosine arabinoside (1 $\mu_{\mathrm{M}}$ ) for another $2 \mathrm{~d}$ to kill rapidly dividing cells. The cells were grown to confluence and plated on $18-\mathrm{mm}$-diameter round glass coverslips (\#1) coated with poly-1-lysine. The final cultures were judged to be $>95 \%$ pure astrocytes, as determined by markers to glial fibrillary acidic protein (GFAP).

Cultures of meningeal cells were obtained from the removed meninges by enzymatic treatments $\left(2 \mathrm{mg} / \mathrm{ml}\right.$ of collagenase, $30-60 \mathrm{~min}$ at $\left.37^{\circ} \mathrm{C}\right)$, followed by trituration (18 gauge needle) to yield a cell suspension. Cells were grown to confluence and plated on poly-l-lysine coated $18 \mathrm{~mm}$ coverslips. Meningeal cell cultures were determined to be $<5 \%$ GFAP positive. All experiments (astrocytic and meningeal) were done on confluent cultures 4-9 weeks old.

Measurement of intracellular $\mathrm{Ca}^{2+}$. Intracellular $\mathrm{Ca}^{2+}$ concentrations $\left(\left[\mathrm{Ca}^{2+}\right]_{i}\right)$ were measured by determining the ratio of the fluorescence of fura-2 at 340 and $380 \mathrm{~nm}$ excitation (Grynkiewicz et al., 1985). Cells were loaded with the dye by incubation in a Locke solution containing fura $2 / \mathrm{AM}(2.5 \mu \mathrm{M})$ and pluronic $(0.07 \%)$ for $30 \mathrm{~min}$ at room temperature. After incubation, the coverslips containing the dye-loaded cells were mounted on a recording chamber and washed continuously in normal Locke solution for $10 \mathrm{~min}$ before beginning fluorescence measurements. Experiments were performed using a SPEX cation mea- surement system (CM110I) in which excitation shutters, monochromator settings, and data acquisition were controlled by a PC/AT computer. Briefly, excitation lights from a $450 \mathrm{~W}$ xenon lamp were narrow-band-filtered at 340 and $380 \mathrm{~nm}$ and passed through an oilimmersion UV-F 40X objective (Nikon). The cells were excited alternately at 340 and $380 \mathrm{~nm}$, and emissions were collected every $3 \mathrm{sec}$ (with signal integrated for $1 \mathrm{sec}$ at each wavelength) and displayed online during experiments. The emission signals were filtered with a 505 $\mathrm{nm}$ narrow-bandpass filter, detected by a Hamamatsu R 928 photondetector, digitized, and stored in a hard disk for later analysis. The cells on the coverslip formed a confluent monolayer and in all experiments, a fixed square diaphragm was used to limit the fluorescence measurement to a field of view which typically containcd $6-10$ cell bodies. $\left[\mathrm{Ca}^{2+}\right]$ (nM) was calculated from the fluorescence ratios (340/380) using the following equation:

$$
\left[\mathrm{Ca}^{2+}\right]_{\mathrm{i}}=K_{D}\left[\left(R-R_{\min }\right) /\left(R_{\max }-R\right)\right]\left(F_{0} / F_{s}\right),
$$

where $R_{\text {min }}=0.42, R_{\max }=12.8, F_{0} / F_{s}=6.79$, and $K_{\mathrm{D}}=224 \mathrm{nM} . R$ is the ratio of the fluorescence intensity excited by 340 and $380 \mathrm{~nm}$, after first correcting for background fluorescence. Background fluorescence was determined after an experiment by bath application of a $\mathrm{Ca}^{2+}$-free Locke solution ( $0 \mathrm{Ca}^{2+}$ plus $2 \mathrm{~mm}$ EGTA) containing $5 \mathrm{~mm} \mathrm{MnCl}_{2}$ and $10 \mu \mathrm{M}$ ionomycin. Following application of this solution, the fluorescence excited by 340 and $380 \mathrm{~nm}$ decreased rapidly $(30-60 \mathrm{sec})$ to a low steady level, presumably resulting from $\mathrm{Mn}^{2+}$ entering the cells and quenching fluorescence from the hydrolyzed from of fura- 2 . The fluorescence which remained (background) should consist of autofluorescence from cells and coverslips, as well as fluorescence from any incompletely hydrolyzed fura-2/AM. The mean background fluorescence was $16.5 \pm 1.7 \%(n=10)$ and $11.5 \pm 0.9 \%(n=10)$ of the total signal at the resting $\mathrm{Ca}^{2+}$ level for $340 \mathrm{~nm}$ and $380 \mathrm{~nm}$ wavelengths, respectively. A background measurement was performed every 1-2 months, and the results were applied to all experiments done during that period. $R_{\max }$, $R_{\min }$, and $F_{0} / F_{s}$ were determined from a series of calibration experiments by exposing the dye-loaded cells first to a Locke solution containing 1.8 $\mathrm{mM} \mathrm{Ca}{ }^{2+}$ and $10 \mu \mathrm{M}$ ionomycin (saturating the cytoplasmic fura-2 with $\left.\mathrm{Ca}^{2+}\right)$, then to a one containing $2 \mathrm{mM}$ EGTA with $\mathrm{Ca}^{2+}$ omitted. $F_{0} / F_{s}$ is the ratio of the $380 \mathrm{~nm}$ excitation fluorescence at zero and saturating $\mathrm{Ca}^{2+}$ levels.

Solutions. The normal Locke solution bathing cells during fluorescence measurements contained (mM): $\mathrm{NaCl}, 142 ; \mathrm{KCl}, 5.4 ; \mathrm{CaCl}_{2}, 1.8$; $\mathrm{MgCl}_{2}, 0.8$; glucose, 11 ; HEPES, 10 (pH 7.4). Several types of modified Locke solutions were used: high- $\mathrm{K}^{+}(\mathrm{NaCl}$ replaced by $\mathrm{KCl}), \mathrm{Ca}^{2+}$-free (omitting $\mathrm{Ca}^{2+}$ and adding $2 \mathrm{mM}$ EGTA), $\mathrm{Mg}^{2+}$-free (omitting $\mathrm{Mg}^{2+}$ ), and $\mathrm{Na}^{+}-$free $(\mathrm{NaCl}$ replaced by choline chloride). Excitatory amino acid agonists and antagonists were added to either normal or modified Locke solutions. Stock solutions of phorbol esters [1 mM in dimethyl sulfoxide (DMSO)] were frozen until use. The volume of the recording chamber was $300 \mu \mathrm{l}$, and astrocytes under study were superfused continuously with control or test solutions at a fixed rate of $1 \mathrm{ml} / \mathrm{min}$.

Whenever possible mean values \pm SEM are given. All fluorescence measurements were done at room temperature.

\section{Results}

\section{Excitatory amino acids induced changes in $\left[\mathrm{Ca}^{2+}\right]_{i}$ in cultured} cortical astrocytes

Figure 1 shows the effects of a maintained bath application of $100 \mu \mathrm{M}$ QA $(A)$, Glu $(B)$, KA $(C)$, and NMDA $(D)$ on $\left[\mathrm{Ca}^{2+}\right]_{\mathrm{i}}$ in highly purified $(>95 \%)$ confluent cultures of neonatal rat cortical astrocytes. The cells were superfused continuously, first with a normal Locke solution for $10 \mathrm{~min}$ to yield a steady baseline in the resting $\left[\mathrm{Ca}^{2+}\right]_{\mathrm{i}}[34 \pm 3.7 \mathrm{nM}(n=103)]$, then to one with agonists added (horizontal bar). The responses shown for the agonists were from different coverslips of cells of the same age (4 weeks) obtained from the same primary culture.

The shape of the responses for QA $(A)$ and Glu $(B)$ is similar; there is an initial large $\left[\mathrm{Ca}^{2+}\right]_{i}$ spike (raising the $\left[\mathrm{Ca}^{2+}\right]_{\mathrm{i}}$ by about $300-400 \mathrm{~nm}$ ), followed by a decaying oscillatory phase. This phase consists of a series of spikes with diminishing amplitudes and a periodicity initially of $20-30 \mathrm{sec}$, but increasing to $40-$ 

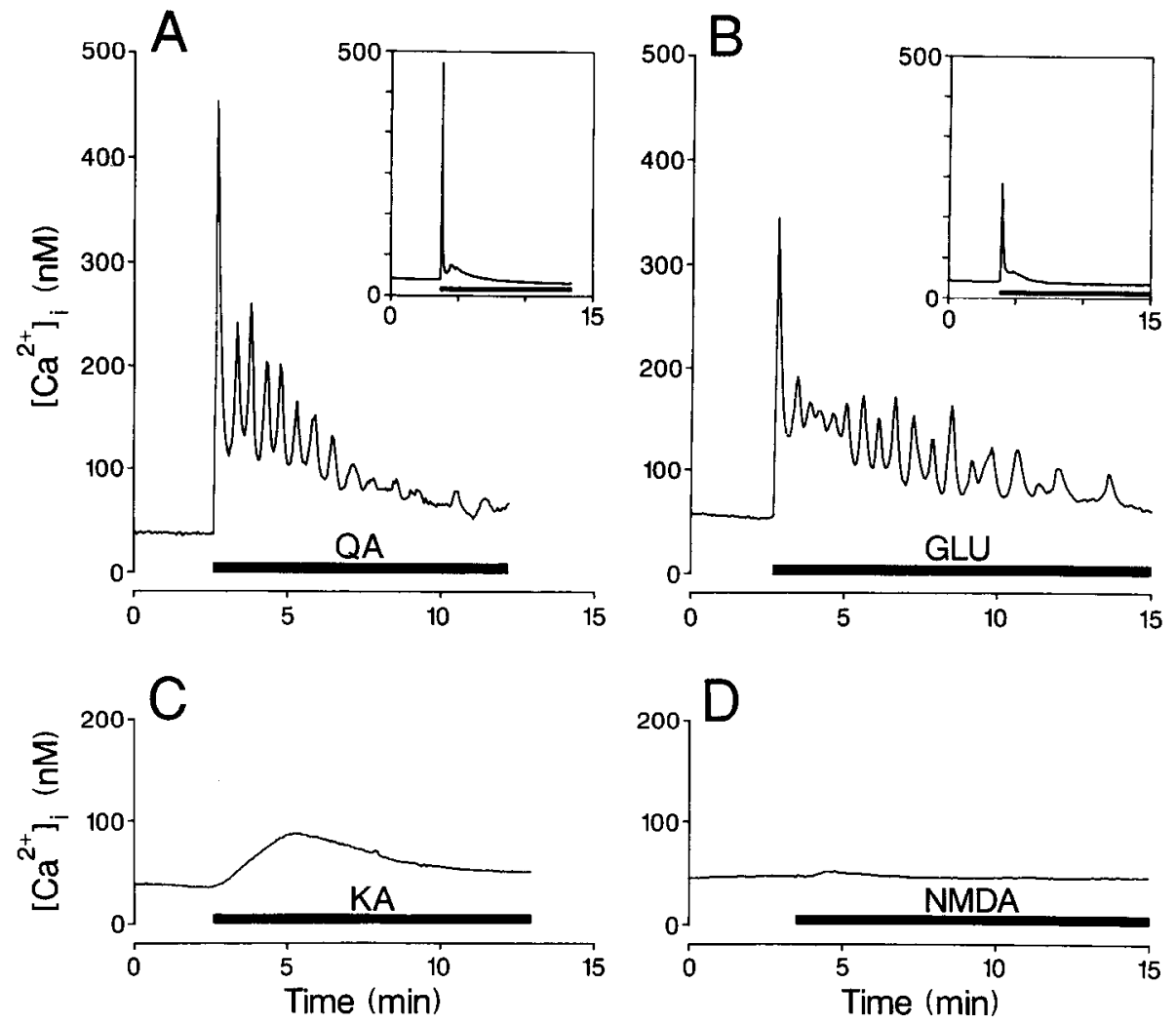

Figure 1. Population response of $\left[\mathrm{Ca}^{2+}\right]_{1}$ induced by excitatory amino acids in confluent cultures of cortical astrocytes. Agonists were applied at 100 $\mu$ M: $A$, quisqualate; $B$, glutamate; $C$, kainate; $D$, NMDA. Cells were perfused continuously, first in a normal Locke solution, then in one containing the agonists as indicated by the horizontal bars. The insets $(A, B)$ show corresponding responses from a different coverslip of cells from the same culture. Cells were 4 weeks old and obtained from the same primary culture. Fluorescence measurements were made from a square field of view on the coverslip containing 6-10 cell bodies.
$100 \mathrm{sec}$ as the response gradually is damped. About $66 \%$ of experiments gave an oscillatory response to QA (4/6) and Glu $(21 / 32)$ during sustained agonist application. While an initial rapid spike was observed consistently in all experiments, the number of oscillations which followed showed some variations; for example, in the experiment of Figure $6 B$ (dotted response) for sustained Glu application, oscillations appear to stop abruptly after 4 spikes, as compared with the more gradual damping shown in Figure $1 B$. In addition, in a few experiments with Glu, oscillations did not appear to be damped out entirely but continued on until the end of the experiment $(15 \mathrm{~min})$. In experiments which did not show oscillations, a distinct secondary slower transient $\left[\mathrm{Ca}^{2+}\right]_{i}$ increasc still is obscrved following the initial fast spike, as shown in insets in Figure $1, A, B$.

Periodicity of $\left[\mathrm{Ca}^{2+}\right]_{i}$ oscillations is examined quantitatively in Figure 2, in which the $i$ th spike is plotted against the mean time following the initial spike for experiments which showed oscillations during sustained Glu $(100 \mu \mathrm{M})$ application. In such a plot, a linear relation represents constant periodicity. However, the data show deviation from this, as can be seen by the straight-line fit to the early phase of oscillations (first 5 spikes). The slope of the line corresponds to a period of $23.5 \mathrm{sec}$ during the first $\sim 100$ sec of oscillations; at later times, however, data deviate from the line in having a slightly steeper slope (longer period).

KA (Fig. 1C), in contrast to QA and Glu (Fig. 1, $A, B$, respectively), elicited a response which is slower in onset and smaller in amplitude, and in which $\left[\mathrm{Ca}^{2+}\right]_{\mathrm{i}}$ oscillations have not been observed. However, like QA and Glu, the response to KA declines during a maintained agonist application.

NMDA (Fig. 1 $D$ ) was found to have virtually no effect on $\left[\mathrm{Ca}^{2+}\right]_{\mathrm{i}}$. Since $\mathrm{Mg}^{2+}(0.8 \mathrm{mM})$ is present in normal Locke solution, and $\mathrm{Mg}^{2+}$ is known to block NMDA-activated ion channels in a voltage-dependent manner in neurons (Nowak et al., 1984; Mayer and Westbrook, 1987), a similar block of the astrocyte NMDA receptor may account for the lack of effect on $\left[\mathrm{Ca}^{2+}\right]_{i}$. This possibility was examined by removing $\mathrm{Mg}^{2+}$ from the bath solution. Figure 3 shows such an experiment in which the astrocytes were superfused for $10 \mathrm{~min}$ with a $\mathrm{Mg}^{2+}$-free Locke solution, followed by a Locke solution containing $500 \mu \mathrm{M}$ NMDA. Clearly, no NMDA response could be seen in the absence of $\mathrm{Mg}^{2+}$, even though the concentration used $(500 \mu \mathrm{M})$ was much higher than that used in Figure $1 D(100 \mu \mathrm{M}) . \mathrm{Mg}^{2+}$ removal evidently has no effect on the Glu response, as can be seen when Glu (100 $\mu \mathrm{M})$ was applied following NMDA exposure (Fig. 3).

Figure 4 shows a plot of the average change in peak $\left[\mathrm{Ca}^{2+}\right]_{i}$ induced by the same agonist concentration (100 $\mu \mathrm{M})$ for QA, Glu, and KA. Also shown is the result for NMDA tested at a higher concentration of $500 \mu \mathrm{M}$, with and without $\mathrm{Mg}^{2+}$ present in the bath. The change in $\left[\mathrm{Ca}^{2+}\right]_{i}$ was measured from the resting level before agonist application to the first peak observed after application. The order of potency in increasing $\left[\mathrm{Ca}^{2+}\right]_{i}$ is $\mathrm{QA}>$ Glu $>$ KA $>>$ NMDA.

Meningeal cells. A major source of contaminating cells in cultures of cortical astrocytes is meningeal cells. Indeed, these cells could account for the $5 \%$ of GFAP-negative cells in astrocyte cultures used in this study. To assess the meningeal contribution to the observed changes in $\left[\mathrm{Ca}^{2+}\right]_{\mathrm{i}}$, excitatory amino agonists were applied to confluent cultures of meningeal cells. The increase in $\left[\mathrm{Ca}^{2+}\right]_{\mathrm{i}}$ in meningeal cultures in response to QA, Glu, and KA was about $0.4 \pm 0.4 \%(n=5), 0.0 \pm 0.0 \%(n=$ $4)$, and $0.9 \pm 0.9 \%(n=4)$ of the corresponding response in astrocyte cultures, at the same agonist concentrations $(100 \mu \mathrm{M})$ and similar culture age (4-9 weeks). 


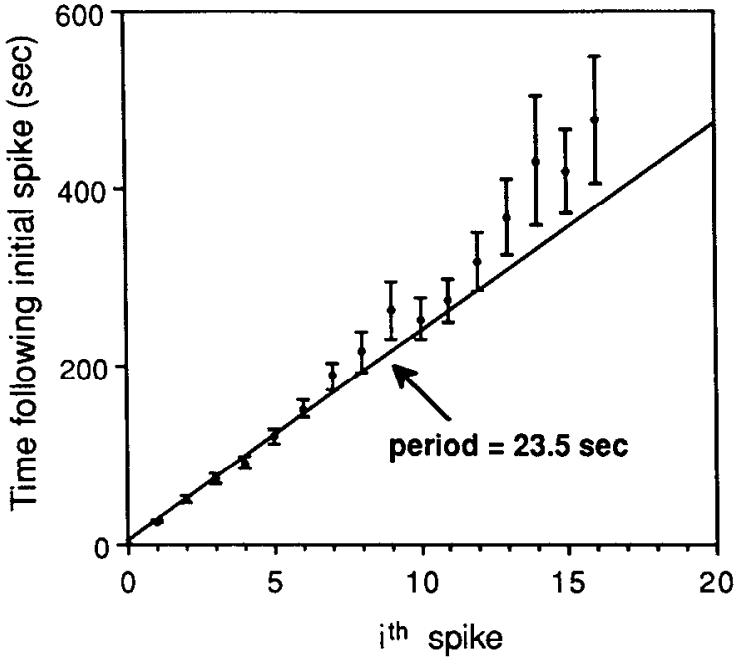

Figure 2. Period of $\left[\mathrm{Ca}^{2+}\right]_{\mathrm{i}}$ oscillations during glutamate application. The $i$ th $\left[\mathrm{Ca}^{2}\right]_{i}$ spike in a series of oscillations (as in Fig. $1 B$ ) is plotted as a function of time following the initial spike. Results represent the mean of 18 experiments, which showed $\left[\mathrm{Ca}^{2+}\right]_{\mathrm{i}}$ oscillations when the bath was perfused continuously with a normal Locke solution plus 100 $\mu_{\mathrm{M}}$ Glu. The straight line represents a linear least-squares fit to the first 5 spikes and has a slope which corresponds to a period of $23.5 \mathrm{sec}$.

\section{Antagonists}

To strengthen the view that the agonist-induced increase in $\left[\mathrm{Ca}^{2+}\right]_{i}$ is mediated by receptors, 2 antagonists for Glu receptors, GAMS (1 mM) and kynurenic acid ( $3 \mathrm{~mm})$, were examined. The astrocyte cultures first were superfused for $3 \mathrm{~min}$ with a Locke solution containing the antagonist, followed by one containing the antagonist plus either Glu $(100 \mu \mathrm{M})$ or KA $(100 \mu \mathrm{M})$. The results are shown in Figure 5. Both responses to Glu and KA appeared to be slightly reduced $(\sim 30 \%)$ by GAMS but were virtually abolished by kynurenic acid.

\section{Effects of external $\mathrm{Ca}^{2+}$}

The observed agonist-induced increase in $\left[\mathrm{Ca}^{2+}\right]_{i}$ could arise from a combination of calcium influx (from the bath) and a release of calcium from internal stores. To examine the relative

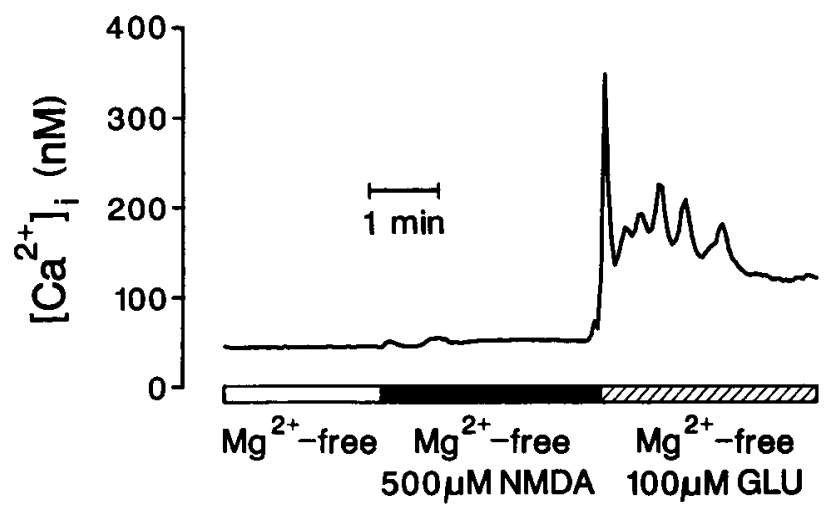

Figure 3. Effects of removal of external $\mathrm{Mg}^{2+}$ on NMDA and Glu response. The astrocytes were perfused continuously with a $\mathrm{Mg}^{2+}$-free Locke solution throughout the experiment. At the indicated times (horizontal bars), NMDA $(500 \mu \mathrm{M})$ and Glu $(100 \mu \mathrm{M})$ were present in the solution.

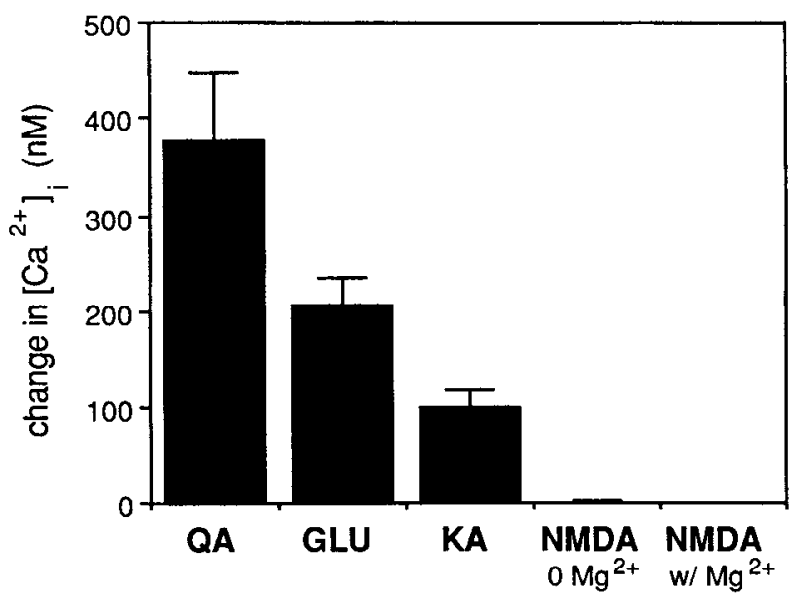

Figure 4. Comparison of peak changes in $\left[\mathrm{Ca}^{2+}\right]_{\text {in }}$ in response to excitatory amino acids. QA, Glu, KA were tested at $100 \mu \mathrm{M}$, while NMDA was at $500 \mu \mathrm{M}$. Agonists were applied in a normal Locke solution (containing $1.8 \mathrm{mM}$ of $\mathrm{Ca}^{2+}$ ) with the exception of the NMDA response obtained in $\mathrm{Mg}^{2+}$-free Locke solution. The change in $\left[\mathrm{Ca}^{2+}\right]_{\text {i }}$ was measured from the resting level before, to the first peak after, agonist application. The numbers of experiments are $n=28$ (QA), $n=46$ (Glu), $n=29$ (KA), $n=5$ (NMDA, $\mathrm{Mg}^{2+}$ present), and $n=4\left(\mathrm{Mg}^{2+}\right.$ free). Results represent an average from cells (4-9 weeks old) derived from different primary cultures.

contribution of influx versus internal release, agonists were applied in a $\mathrm{Ca}^{2+}$-free external environment. Astrocytes wcre superfused continuously for a period of 10-15 min with a $\mathrm{Ca}^{2+}$ free Locke solution ( $0 \mathrm{Ca}^{2+}$ plus $2 \mathrm{~mm}$ EGTA) to remove $\mathrm{Ca}^{2+}$ from the bath. At the end of this period, the resting $\left[\mathrm{Ca}^{2+}\right]_{i}$ was lowered to $23 \pm 4 \mathrm{nM}(n=37)$ as compared with the normal resting $\left[\mathrm{Ca}^{2+}\right]_{\mathrm{i}}$ of $34 \pm 3.7 \mathrm{nM}$. Figure 6 shows the effects on $\left[\mathrm{Ca}^{2+}\right]_{\mathrm{i}}$ when QA $(A)$, Glu $(B)$, and $\mathrm{KA}(C)$ were applied at the end of this $\mathrm{Ca}^{2+}$-free incubation (solid curves). For a comparison, examples of typical responses to the same agonist concentration in normal external $\mathrm{Ca}^{2+}$ are superimposed (dotted curves). Further, the resting $\left[\mathrm{Ca}^{2+}\right]_{\mathrm{i}}$ level has been subtracted from the data so that only changes in $\left[\mathrm{Ca}^{2+}\right]_{\mathrm{i}}$ are shown.

Removal of external $\mathrm{Ca}^{2+}$ had 3 distinct effects on the $\left[\mathrm{Ca}^{2+}\right]_{\mathrm{i}}$ response induced by QA and Glu. First, the peak amplitude was reduced. Second, at least for Glu, the time to peak for the first spike was prolonged about 2 -fold: $15.9 \pm 2 \sec (n=13)$ as compared with the normal of $7 \pm 0.4 \sec (n=21)$ in the presence of external $\mathrm{Ca}^{2+}(p<0.002, t$ test $)$. Third, unlike a normal response, which often showed a series of oscillatory spikes, $\left[\mathrm{Ca}^{2+}\right]$ declined in a monotonic fashion after the first peak in $5 / 10$ and $11 / 15$ experiments for sustained application of QA and Glu, respectively; in the remaining experiments, only one spike was observed following the initial peak.

In comparison to QA and Glu, no response could be elicited by $\mathrm{KA}(100 \mu \mathrm{M})$ following the $\mathrm{Ca}^{2+}$-free incubation (Fig. $6 \mathrm{C}$ ). An absent response was observed in 10 out of 14 experiments. However, in the remaining 4 experiments, KA elicited a transient increase in $\left[\mathrm{Ca}^{2+}\right]_{i}$ lasting only $1-2 \mathrm{~min}$, as distinct from the normally much more prolonged $\mathrm{KA}$ response. To examine the kinetics of the effect of removing $\mathrm{Ca}^{2+}$ on the $\mathrm{KA}$ response, experiments were done in which bath $\mathrm{Ca}^{2 ;}$ was removed during agonist exposure. Figure 7 shows an experiment in which a normal response to $\mathrm{KA}$ first is initiated with $\mathrm{Ca}^{2+}$ present in the bath. At around the peak of the response, $\mathrm{Ca}^{2+}$, but not the 


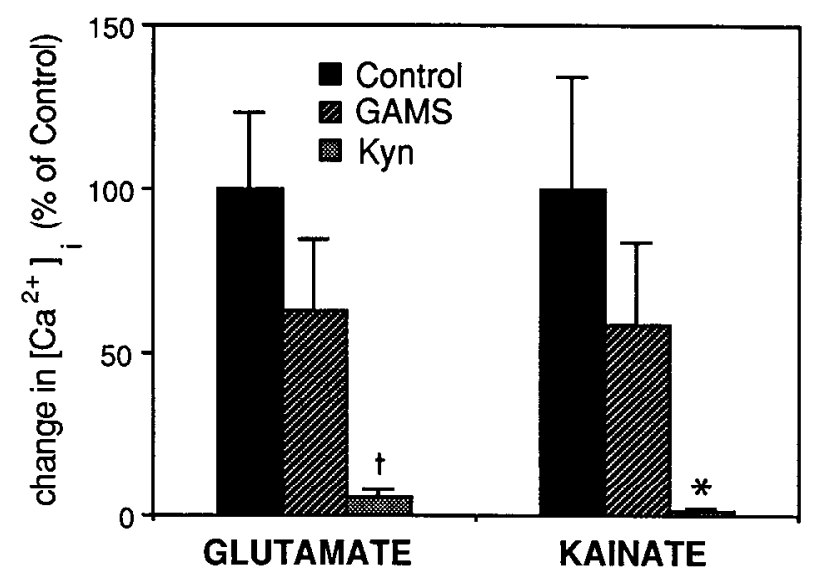

Figure 5. Effects of antagonists GAMS (1 mM) and kynurenic acid (3 $\mathrm{mm}$ ) on Glu- and KA-induced changes in $\left[\mathrm{Ca}^{2+}\right]_{i-}$ The numbers of experiments are $n=10$ (control), $n=4$ (GAMS), and $n=6$ (kynurenic acid) for Glu, and $n=9$ (control), $n=3$ (GAMS), and $n=4$ (kynurenic acid) for $\mathrm{KA}$. Control and test responses were obtained from age-matched cultures from the same primary cultures. Dagger $(\dagger)$ and asterisk $\left(^{*}\right)$ designate significantly different from control with $p<0.001$ and $p<$ 0.05 , respectively.

agonist, is removed from the bath solution. It can be seen that this leads to a decline of $\left[\mathrm{Ca}^{2+}\right]_{i}$ to near the baseline, the decline occurring in a rapid phase followed by a slower one. Upon reintroduction of $\mathrm{Ca}^{2+}$ to the bath, $\left[\mathrm{Ca}^{2+}\right]_{i}$ rises rapidly. Finally, removal of agonist from the bath results in a decline in $\left[\mathrm{Ca}^{2+}\right]_{i}$ which is similar in shape to that obtained during removal of bath $\mathrm{Ca}^{2+}$.

Figure 8 shows mean results (from experiments as in Fig. 6) by plotting the peak change in $\left[\mathrm{Ca}^{2+}\right]_{i}$ induced by agonists in $\mathrm{Ca}^{2+}$-free bath relative to the control obtained in the presence of bath $\mathrm{Ca}^{2+}$. Compared with control, the peak response is reduced to 40,34 , and $18 \%$ for QA, Glu, and KA, respectively.

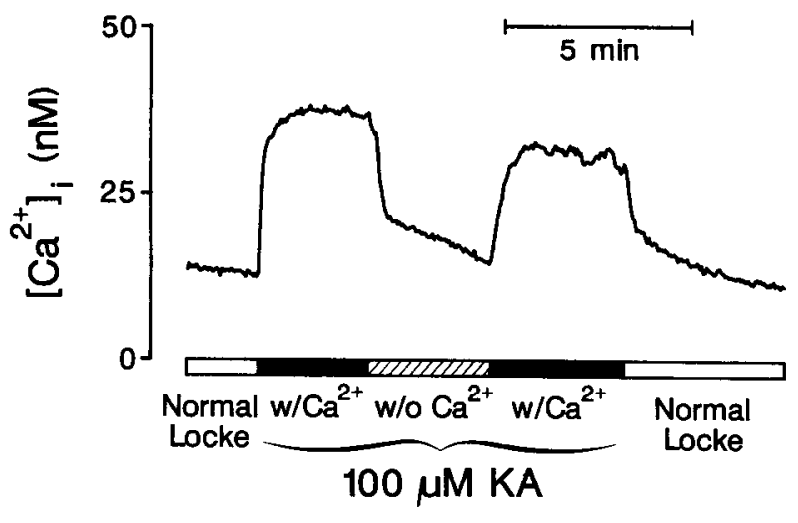

Figure 7. Effects of removal of external calcium during KA exposure. Cells were perfused continuously with solutions changed in the following order as indicated by the horizontal bar: normal Locke, normal Locke $+\mathrm{KA}, \mathrm{Ca}^{2+}$-free Locke $+\mathrm{KA}$, normal Locke $+\mathrm{KA}$, and normal Lockc. KA was used at $100 \mu \mathrm{M}$.

\section{Role of protein kinase $C$}

MacVicar et al. (1987) recently have reported oscillations in membrane potentials in astrocytes induced by phorbol esters and suggested that protein kinase $C$ activation may lead to oscillations in cytoplasmic $\mathrm{Ca}^{2+}$ concentrations. In the present study, bath application of the phorbol ester PMA (100 nM), a potent protein kinase $\mathrm{C}$ activator, was found to have no effect on the resting $\left[\mathrm{Ca}^{2+}\right]_{i}$, and no evidence for an oscillatory response was found for up to $15 \mathrm{~min}$ of application. However, the work of MacVicar et al. (1987) cannot be so easily compared with the present study because their study examined reactive astrocytes, which not only are pathologic, but could even be a different cell type since they have not been conclusively shown to be derived from type- 1 astrocytes.

Even though phorbol ester incubation did not induce $\left[\mathrm{Ca}^{2+}\right]_{i}$ oscillation in this study, it was observed that subsequent Glu-

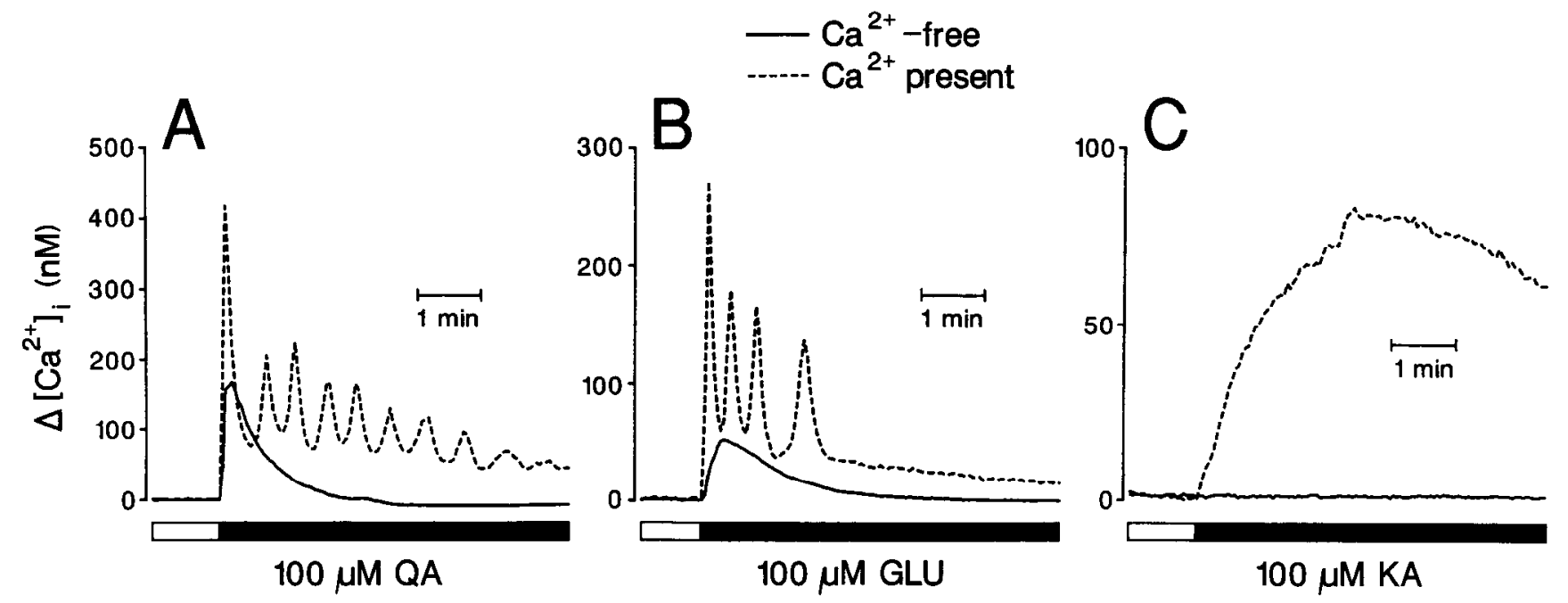

Figure 6. Effects of removal of external calcium on $\left[\mathrm{Ca}^{2+}\right]_{\mathrm{i}}$ response to $\mathrm{QA}(A)$, Glu $(B)$, and KA $(C)$. Cells were perfused continuously, first with a $\mathrm{Ca}^{2+}$-free Locke solution ( $0 \mathrm{Ca}^{2+}$ plus $2 \mathrm{mM}$ EGTA) for $10 \mathrm{~min}$ (only the last minute is shown), then by a $\mathrm{Ca}^{2+}$-free Locke solution plus $100 \mu \mathrm{M}$ agonist (indicated by the horizontal bars). The responses are shown as the solid curves. For comparison, examples of responses obtained in the presence of normal external calcium $(1.8 \mathrm{~mm})$ are shown as dotted curves. Note that only changes in $\left[\mathrm{Ca}^{2+}\right]_{i}$ are shown; the resting $\left[\mathrm{Ca}^{2+}\right]_{i}$ level has been subtracted from the data for display. 


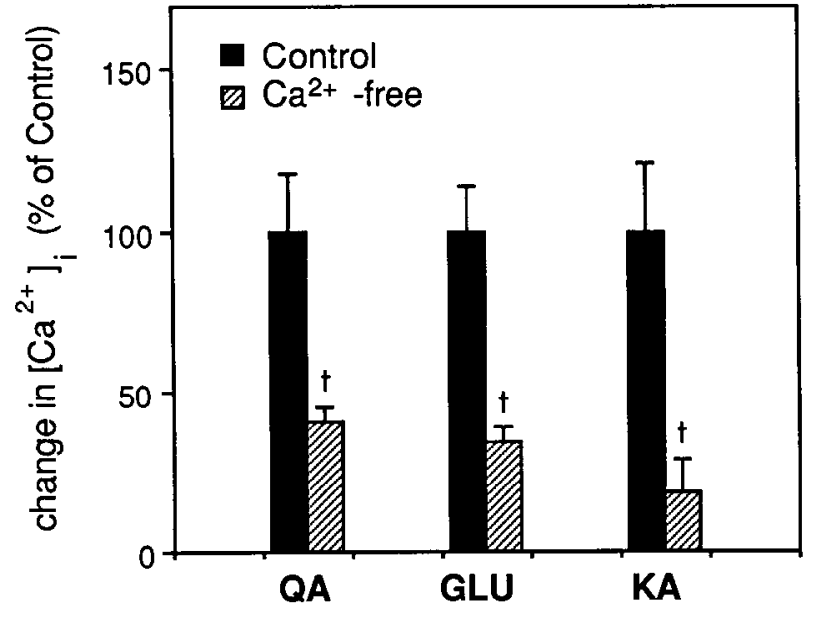

Figure 8. Agonist-induced changes in peak $\left[\mathrm{Ca}^{2+}\right]_{i}$ in the presence and absence of external calcium. Agonists $(100 \mu \mathrm{M})$ were applied either in control Locke $\left(1.8 \mathrm{mM} \mathrm{Ca}^{2+}\right)$ or $\mathrm{Ca}^{2+}$-free Locke $\left(0 \mathrm{Ca}^{2+}\right.$ plus $2 \mathrm{~mm}$ EGTA). The numbers of experiments for control and tests are as follows: $n=28,11$, QA; $n=46,13$ for Glu; and $n=29,13$ for KA. Dagger $(\dagger)$ designates significantly different from control with $p<0.005$.

and QA-induced rise in $\left[\mathrm{Ca}^{2+}\right]_{\mathrm{i}}$ was reduced markedly. A series of experiments therefore was designed to examine the effects of protein kinase $C$ activation on agonist-induced changes in $\left[\mathrm{Ca}^{2+}\right]_{i}$. Figure 9 shows a typical experiment. Astrocytes are subjected to a brief exposure of $100 \mu \mathrm{M}$ agonists ( $30 \mathrm{sec}$ for QA and Glu, 3 min for KA) followed by a wash in agonist-free, normal Locke solution for 8-10 min. Inactive (PDD, left column) and active (PMA, right column) analogs of phorbol ester are then applied (100 nM) continuously for $15 \mathrm{~min}$. At the end of this phorbol ester treatment, the astrocytes are exposed again to the same concentrations of agonists. Only changes in $\left[\mathrm{Ca}^{2+}\right]_{\mathrm{i}}$ relative to those from the first agonist response are shown. It can be seen that following treatment with the active phorbol ester analog, both the QA and Glu responses are markedly reduced. Not all of this reduction can be explained by receptor desensitization after the first agonist application, since a significant second response is still seen after treatment with the inactive analog. Further, even though control experiments with the inactive phorbol ester, PDD, suggest that the inhibition by PMA is not nonspecific, a more stringent control would be the corresponding inactive analog of PMA itself, namely, $\alpha$-PMA. Indeed, in 2 experiments, $\alpha$-PMA, like PDD, did not block the Glu-induced $\left[\mathrm{Ca}^{2+}\right]_{i}$ response. These studies strongly suggest that activation of protein kinase $\mathrm{C}$ has an inhibitory effect on the ability of QA and $\mathrm{Glu}$ to increase $\left[\mathrm{Ca}^{2+}\right]$. In contrast, no inhibition on the KA response could be detected (Fig. 9, bottom).

The results are summarized in Figure 10, in which the response to agonist following active phorbol ester treatment (PMA) is expressed relative to the corresponding response following inactive phorbol ester treatment (PDD).

\section{Effects of external sodium}

Astrocytes are known to express a high-affinity uptake of Glu which is dependent on the presence of external sodium. to examine whether the Glu-induced increase in $\left[\mathrm{Ca}^{2+}\right]_{\mathrm{i}}$ is related to this high-affinity uptake, the membrane carrier which cotransports $\mathrm{Na}^{+}$and Glu into astrocytes is inhibited by replacing the external $\mathrm{Na}^{+}$with choline. In the experiment shown in Figure $11 \mathrm{~A}$, the normal Locke solution bathing the astrocytes is switched to a $\mathrm{Na}^{+}$-free Locke solution $\left(\mathrm{Na}^{+}\right.$replaced by choline) as indicated (horizontal bar). This produces no change in the resting $\left[\mathrm{Ca}^{2+}\right]_{\text {. }}$. After $6 \mathrm{~min}$ of $\mathrm{Na}^{+}$-free incubation, Glu $(100 \mu \mathrm{M})$ is applied to the $\mathrm{Na}^{+}$-free Locke solution. A transient response in $\left[\mathrm{Ca}^{2+}\right]$, resembling that normally obtained in the presence of $\mathrm{Na}^{+}$, is elicited. Further, in 2 out of 6 experiments, oscillations in $\left[\mathrm{Ca}^{2+}\right]_{i}$ also were observed in $\mathrm{Na}^{+}$-free environment. Compared with the control response ( $\mathrm{Na}^{+}$present) obtained in agematched cultures from the same primary culture, the peak increase in $\left[\mathrm{Ca}^{2+}\right]_{i}$ induced by Glu appears to be enhanced in $\mathrm{Na}^{\prime}$-free conditions (Fig. 11B); however, this is not statistically significant ( $90 \%$ confidence level, $t$ test), possibly due to small sample size. Hence, inhibition of the $\mathrm{Na} / \mathrm{Glu}$ cotransporter produces no corresponding inhibition of the Glu-induced increase in $\left[\mathrm{Ca}^{2+}\right]_{\mathrm{i}}$.

\section{Effects of membrane depolarization}

External application of Glu is known to cause a rapid membrane depolarization in cultured astrocytes (Bowman and Kimelberg, 1984; Kettenmann and Schachncr, 1985). The transient increase in $\left[\mathrm{Ca}^{2+}\right]_{i}$ following Glu application may be mediated by this membrane depolarization, for example, via activation of voltage-gated $\mathrm{Ca}^{2+}$ channels known to be present in cultured astrocytes (MacVicar, 1984). This possibility was explored in experiments in which astrocytes were depolarized by high $\mathrm{K}^{+}$. Bath application of $50 \mathrm{~mm} \mathrm{~K} \mathrm{~K}^{+}$-Locke solution was found to result in a transient increase in $\left[\mathrm{Ca}^{2}\right]_{i}$, suggesting that membrane depolarization accompanying glutamate exposure may account for some of the observed increase in $\left[\mathrm{Ca}^{2+}\right]_{i}$. However, as the experiment in Figure 12 shows, not all the $\left[\mathrm{Ca}^{2+}\right]_{\mathrm{i}}$ increase can be so explained. Here, the astrocytes first are depolarized to around $0 \mathrm{mV}$ by bath application of an isotonic $\mathrm{K}^{+}$-Locke solution containing $148 \mathrm{mM} \mathrm{KCl}\left(\mathrm{Na}^{+}\right.$replaced by $\left.\mathrm{K}^{+}\right)$. A large transient rise in $\left[\mathrm{Ca}^{2+}\right]_{i}$ is observed, presumably resulting from the depolarization. After incubation in $\mathrm{K}^{+}$-Locke solution for $6 \mathrm{~min}$, Glu $(100 \mu \mathrm{M})$ is added to the $\mathrm{K}^{+}$solution. $\Lambda$ transient $\left[\mathrm{Ca}^{2+}\right]_{i}$ response is induced. Similar results also were observed ( 2 experiments) when external $\mathrm{K}^{+}$was raised by adding $\mathrm{KCl}$ to a normal Locke solution (making it hypertonic). The Glu-induced rise in $\left[\mathrm{Ca}^{2+}\right]_{\mathrm{i}}$ in high $\mathrm{K}^{+}$(Fig. 12) is unlikely to be accompanied by any further membrane depolarizations; already, the membrane potential is around $0 \mathrm{mV}$, which is close to the reversal potential suggested for the Glu-activated $\mathrm{Na}^{+} / \mathrm{K}^{+}$channels recently described in cultured astrocytes (Sontheimer et al., 1988; Usowicz et al., 1989). Thus, at least part of the normal increase in $\left[\mathrm{Ca}^{2+}\right]_{\mathrm{i}}$ induced by Glu (e.g., Fig. $1 B$ ) appears to be independent of membrane depolarizations.

\section{Discussion}

It has been known for some time that astrocytes in culture express receptors for excitatory amino acids and that some of these receptors mediate hydrolysis of inositol lipids (for review, see Pearce and Murphy, 1988). Even though intracellular calcium in astrocytes has been measured using fluorescent indicators, the only complete studies to date have been on astrocytoma cell lines (Sugino et al., 1984; Shain et al., 1989). This study, together with several recent ones, provided fluorescence measurement of $\left[\mathrm{Ca}^{2+}\right]_{\mathrm{i}}$ in astrocytes cultured from normal neonatal mammalian brains (Ahmed et al., 1989; Finkbcincr ct al., 1989; Jensen and Chiu, 1989; Vijendra and McCarthy, 1989). Compared with previous calcium flux studies using radio-tracers $\left({ }^{45} \mathrm{Ca}^{2+}\right)$ in astrocytes, this study yields new information on both 
C2ZZZ Inactive phorbol ester (PDD) Agonist
Z2Z2A Active phorbol ester (PMA)

Agonist

Normal Locke
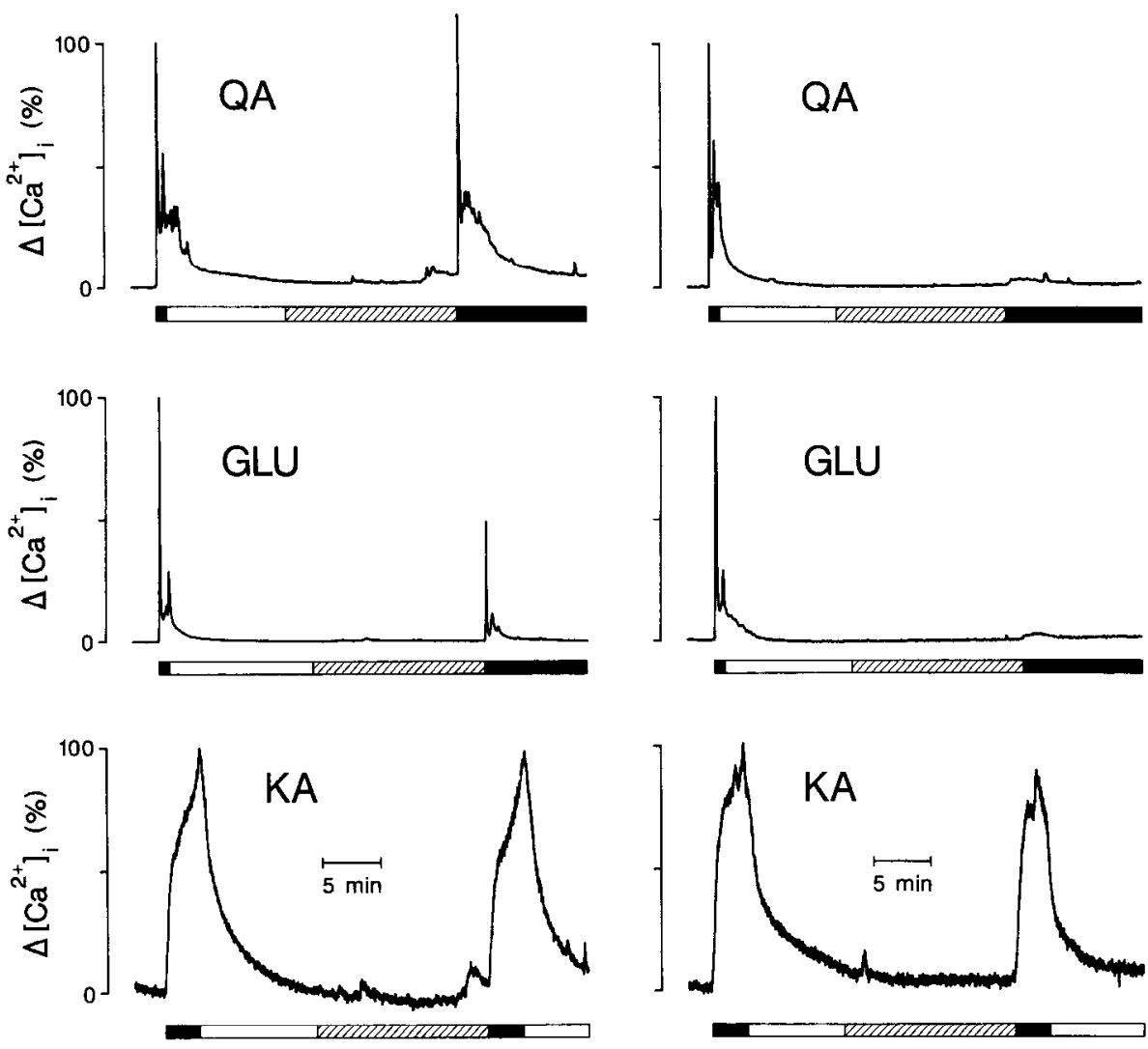

Figure 9. Effects of inactive (left column) and active (right column) phorbol esters on agonist-induced changes in $\left[\mathrm{Ca}^{2+}\right]_{i}$ In each experiment, cells were perfused continuously with solutions as indicated by the horizontal bars in the following order: $100 \mu \mathrm{M}$ agonist (30 sec for QA and Glu; $3 \mathrm{~min}$ for KA), normal Locke (8-10 min), 100 nM phorbol ester in Locke (15 min), and $100 \mu \mathrm{M}$ agonist. Note that only changes in $\left[\mathrm{Ca}^{2+}\right]_{i}$ are plotted (by subtracting baseline $\left[\mathrm{Ca}^{2+}\right]$ from the data). Further, the response has been normalized to the peak response from the first agonist exposure. Active phorbol ester used was PMA and inactive analog used was PDD. the magnitude and kinetics of the $\left[\mathrm{Ca}^{2+}\right]_{i}$ response induced by excitatory amino acids. The results reveal, at least in vitro, a dynamic picture of the response, particularly in the existence of oscillatory $\left[\mathrm{Ca}^{2+}\right]_{i}$ signaling which may be important to astrocyte physiology.

Cellular origin of the observed $\left[\mathrm{Ca}^{2+}\right]_{i}$ changes. Meningeal contribution to the observed $\left[\mathrm{Ca}^{2+}\right]_{\mathrm{i}}$ response was shown to be insignificant in control expcriments using highly purified cultures of meningeal cells. Further, even though amino acids have been shown to induce a $\left[\mathrm{Ca}^{2+}\right]_{\mathrm{i}}$ rise in cultured CNS neurons in experiments using fura-2 (Murphy et al., 1987), it is unlikely that the $\left[\mathrm{Ca}^{2+}\right]_{i}$ response observed in this study is neuronal. First, neurons are known not to survive the procedures used here to obtain the cortical cultures, particularly in rats older than postnatal day 2 (McCarthy and De Vellis, 1980). Second, a Gluinduced increase in $\left[\mathrm{Ca}^{2+}\right]_{i}$ still could be observed in very old cultures (4-5 months, data not shown); it is highly improbable that neurons could have survived in these cultures. Third, neuronal $\left[\mathrm{Ca}^{2+}\right]_{i}$ response to Glu, at least in mouse cultured striatal neurons (Murphy et al., 1987), is reported to be abolished when external $\mathrm{Ca}^{2+}$ is removed. In the present study, a significant $(\sim 34 \%)$ portion of the response to Glu still remains (Fig. 8 ). Fourth, no response to NMDA could be observed in astrocyte cultures, even when tested in relatively high concentrations (500 $\mu \mathrm{M})$ and in the absence of $\mathrm{Mg}^{2+}$ known to block NMDA-activated ion channels in neurons (Figs. 3,4). In comparison, at least in striatal neurons, a large NMDA-induced change in $\left[\mathrm{Ca}^{2+}\right]_{\mathrm{i}}$

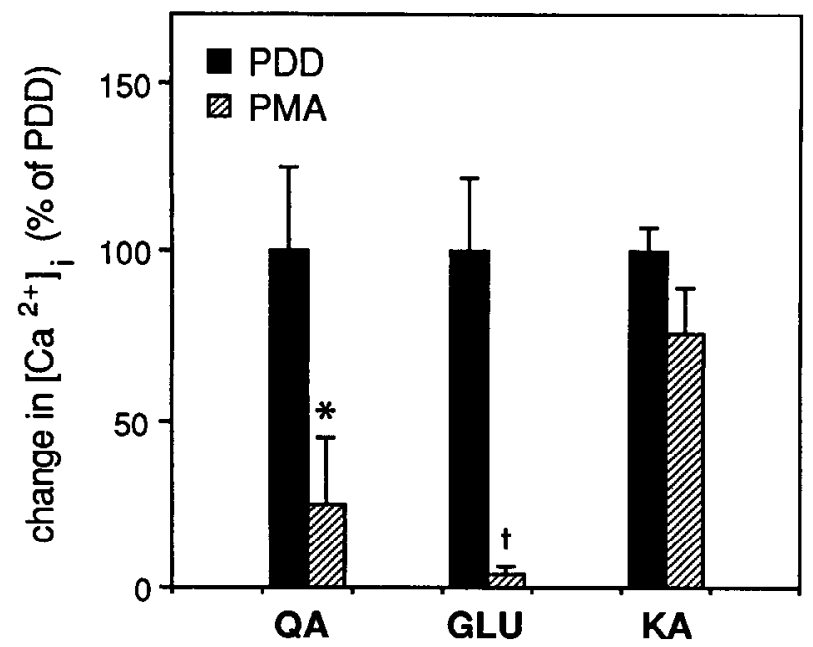

Figure 10. Comparison of agonist-induced changes in $\left[\mathrm{Ca}^{2+}\right]_{\mathrm{i}}$ following inactive (PDD) and active (PMA) phorbol ester treatment. Results were obtained from experiments such as those shown in Figure 9. The agonistinduced response following phorbol ester treatment (both PDD and PMA) was calculated as a percentage of the first agonist-induced response. Means of these percentage responses were calculated for PDD and PMA. These 2 means then were normalized to the mean \% PDD. The numbers of experiments for PDD and PMA are as follows: $n=4$, 4, for QA; $n=4,4$, Glu; and $n=5,5$, KA. Dagger $(\dagger)$ and asterisk $\left(^{*}\right)$ designate significantly different from control with $p<0.05$ and $p<$ 0.09 , respectively. 
Figure 11. Effects of removal of external $\mathrm{Na}^{+}$on changes in $\left[\mathrm{Ca}^{2+}\right]$; induced by Glu. $A$, Cells were perfused continuously with solutions in the following order: normal Locke, $\mathrm{Na}^{+}$-free Locke $\left(\mathrm{Na}^{+}\right.$replaced by $142 \mathrm{~mm}$ choline), $\mathrm{Na}^{+}-$ free Locke plus $100 \mu \mathrm{M}$ glutamate. $B$, Mean peak change in $\left[\mathrm{Ca}^{2+}\right]_{i}$ induced by Glu $(100 \mu \mathrm{M})$ in the presence and absence of external $\mathrm{Na}^{+}$. The number of experiments are $n=10$ (control, $\mathrm{Na}^{+}$ present) and $n=4\left(\mathrm{Na}^{+}\right.$free).
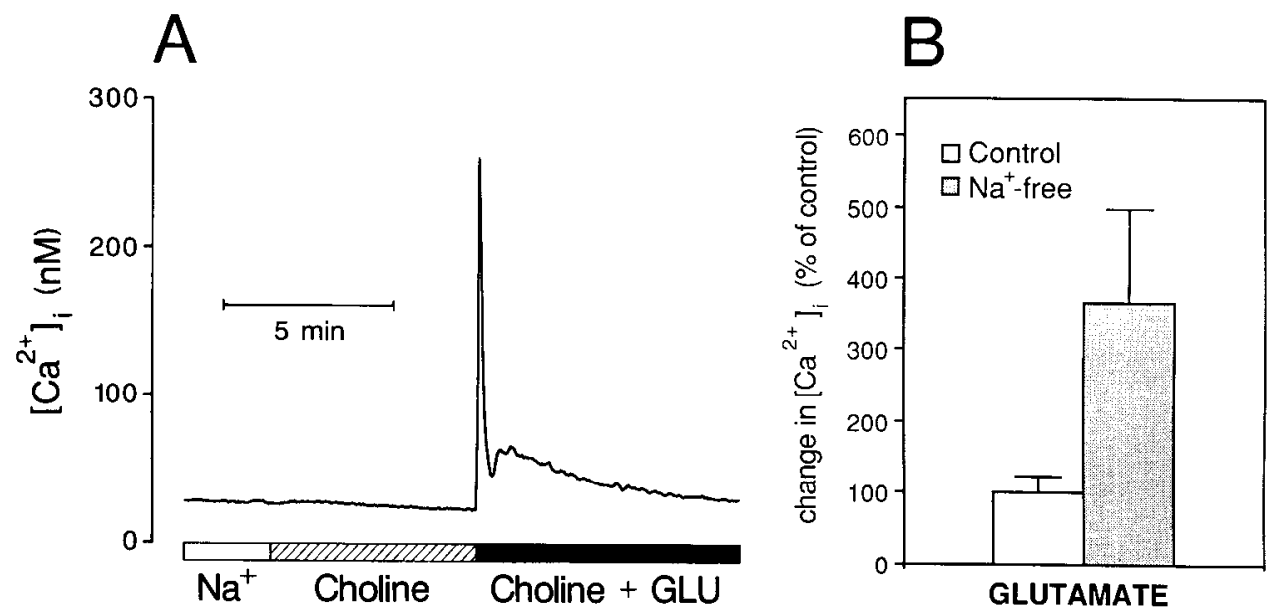

is observed under similar conditions (Murphy et al., 1987). Finally, a neuronal marker, a polyclonal antibody to neurofilament protein, did not stain our astrocyte cultures ( 2 experiments).

Astrocyte phenotype. Two types of astrocytes are known to be present in the CNS; type- 1 is found predominantly in gray matter and has a flat, fibroblastic appearance, while type-2 is thought to occur mainly in the white matter and has a stellar appearance in culture. Even though no distinction has been made in the astrocyte phenotype in the present experiments, the procedures adopted here for cortical cultures have been found to yield mostly type- 1 astrocytes. However, the possibility remains that type2 astrocytes were present to some degree in the cultures and contributed to the population response in $\left[\mathrm{Ca}^{2+}\right]_{\mathrm{i}}$. Indeed, while most GFAP-positive cells in this study were flat and type-1like, stellar-like cells were sometimes observed. However, it is unclear whether these cells were type- 2 astrocytes or type- 1 astrocytes which attained process-bearing appearance in response to culture conditions. Whether some of the variations in the $\left[\mathrm{Ca}^{2+}\right]_{i}$ response to the same agonist, for example, the degree of oscillations in the second phase for Glu, could be so explained remains an interesting possibility. In some experiments in which only flat-looking cells were chosen for fluorescence measurements, the response to Glu obtained (including the cxistence of $\left[\mathrm{Ca}^{2+}\right]_{\text {i }}$ oscillations) was qualitatively similar to that in most experiments in which the field of measurement was chosen randomly.

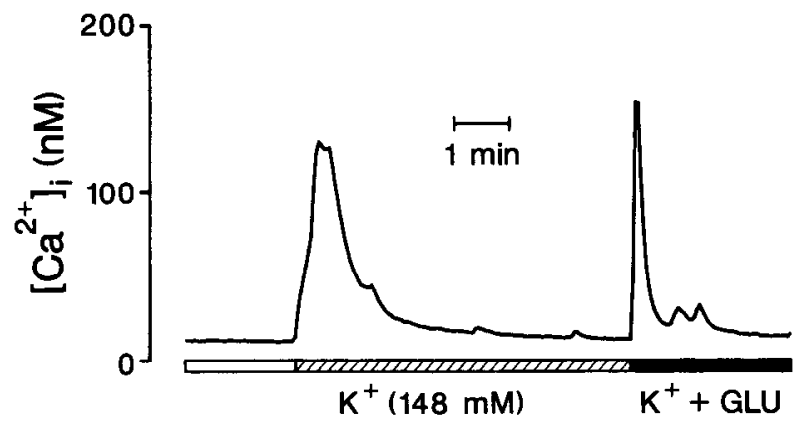

Figure 12. Effects of isotonic $\mathrm{K}^{+}$-Locke solution on changes in $\left[\mathrm{Ca}^{2+}\right]_{\mathrm{i}}$ induced by Glu. Cells were perfused continuously with solutions in the following order: normal Locke solution, isotonic $\mathrm{K}^{+}$-Locke solution (148 mм $\mathrm{K}^{+}$), isotonic $\mathrm{K}^{+}$-Locke solution plus $100 \mu \mathrm{M}$ glutamate.

\section{Source of rise in $\left.\mathrm{CCa}^{2+}\right]_{i}$ for $Q A$ and Glu}

By comparing agonist-induced responses in the presence and absence of external $\mathrm{Ca}^{2+}$ (Fig. 8), it appears that $30-40 \%$ of the peak increase in $\left[\mathrm{Ca}^{2+}\right]_{i}$ arises from internal release, with the remaining from $\mathrm{Ca}^{2+}$ influx from the bath.

Internal release. This release most likely reflects the generation of the second messenger IP3, which is known to trigger the release of $\mathrm{Ca}^{2+}$ from internal stores. Receptor-mediated hydrolysis of inositol lipids has been extensively studied in cultures of both normal cortical mammalian astrocytes and astrocytoma cell lines (for review, see Pearce and Murphy, 1988). Indeed, the reported order of potency for inositol lipid hydrolysis is QA $>$ Glu $>>\mathrm{KA}>>>\mathrm{NMDA}$, which is similar to that for increasing $\left[\mathrm{Ca}^{2+}\right]_{i}$ reported in this study.

Influx from bath. One possible pathway for $\mathrm{Ca}^{2+}$ influx is via the $\mathrm{Na}^{+} / \mathrm{Ca}^{2+}$ exchanger. This could occur if there is a agonistinduced $\mathrm{Na}^{+}$influx via the $\mathrm{Na} / \mathrm{Glu}$ cotransporter and a Gluactivated, $\mathrm{Na}^{+}$-permeable channel (Sontheimer et al., 1988; Usowicz et al., 1989). A rise in internal $\mathrm{Na}^{+}$may affect the net flux via the $\mathrm{Na}^{+} / \mathrm{Ca}^{2+}$ exchanger; instead of exchanging $\mathrm{Na}^{+}$ influx for $\mathrm{Ca}^{2+}$ efflux, the exchanger is exchanging $\mathrm{Na}^{+}$influx for $\mathrm{Na}^{+}$efflux. The net result is a rise in $\left[\mathrm{Ca}^{2+}\right]_{i}$ If this is the major mechanism underlying the rise in $\left[\mathrm{Ca}^{2+}\right]_{i}$ induced by Glu, then the following response is predicted when extcrnal $\mathrm{Na}^{+}$is removed: There should be a rise in $\left[\mathrm{Ca}^{2+}\right]_{i}$ when cells are perfused with a $\mathrm{Na}^{+}$-free Locke solution, but no further $\left[\mathrm{Ca}^{2+}\right]_{i}$ rise when Glu is added to the $\mathrm{Na}^{+}$-free Locke solution. Figure 11 shows that an opposite result is obtained: There was no detectable rise in $\left[\mathrm{Ca}^{2+}\right]_{\mathrm{i}}$ upon perfusion with the $\mathrm{Na}^{+}$-free Locke, and a large rise in $\left[\mathrm{Ca}^{2+}\right]_{\mathrm{i}}$ was observed when Glu was added to the $\mathrm{Na}^{+}$free solution. This result of this experiment suggests that the role played by the $\mathrm{Na}^{+} / \mathrm{Ca}^{2+}$ exchanger in $\left[\mathrm{Ca}^{2+}\right]_{\mathrm{i}}$ regulation in astrocytes may not be very significant. On the other hand, some evidence in this study potentially suggests a role for the exchanger: the $\mathrm{Na} / \mathrm{Ca}$ exchange mechanism is electrogenic, and thus depolarization caused by raising external $\mathrm{K}^{+}$(as in Fig. 12) would be expected to increase intracellular calcium, as was indeed observed.

The most likely pathway for influx is via ion channels. The first type is voltage-gated ion channels. $\mathrm{Ca}^{2+}$ channels, known to be present in cultured cortical astrocytes (MacVicar, 1984; Barres et al., 1988), could be activated by the membrane depolarization resulting from Glu application (Bowman and $\mathrm{Ki}$ - 
melberg, 1984; Kettenmann et al., 1984). The observation that $\mathrm{K}^{+}$-depolarization did induce a transient rise in $\left[\mathrm{Ca}^{2+}\right]_{\mathrm{i}}$ (Fig. 12) suggests that $\mathrm{Ca}^{2+}$ channels were present in our cultures and can, in principle, mediate $\left[\mathrm{Ca}^{2+}\right]_{\mathrm{i}}$ increase. Interestingly, preliminary studies showed that Glu response elicited after incubation in isotonic $\mathrm{K}^{+}$solution (presumably resulting in $\mathrm{Ca}^{2+}$ channel inactivation) appeared to have a smaller secondary $\left[\mathrm{Ca}^{2+}\right]_{i}$ phase. One argument against a role of voltage-gated calcium channels in mediating $\mathrm{Ca}^{2+}$ influx is that cortical type- 1 astrocytes in neuron-free cultures have not been found to possess voltagegated calcium channels unless first treated with substances that increase their intracellular cAMP (Barres et al., 1989). However, it is possible that our cultures contained some type-2 astrocytes, which are known to have voltage-gated calcium channels. Further, there have been reports of plasma membrane channels activated by IP3 which are permeable to calcium (Kuno and Gardner, 1987); similar channels may exist in astrocytes.

Besides $\mathrm{Ca}^{2+}$ channels, astrocytes possess several other types of neuronal-like channels, such as voltage-gated $\mathrm{Na}^{+}$and $\mathrm{K}^{+}$ channcls (Bevan et al., 1985; Barres et al., 1988); in nerves these channels have a measurable permeability to $\mathrm{Ca}^{2+}$ (for review, see Hille, 1975; Inoue, 1981). In astrocytes there is usually a very low density of voltage-gated $\mathrm{Na}^{+}$channels once they become confluent (J. M. Ritchie and H. Sontheimer, unpublished observations). In early cultures that are not confluent, there may be enough $\mathrm{Na}^{+}$channels present to mediate the $\mathrm{Ca}^{2+}$ flux, but this would not be the case for the 4- to 5-month-old cultures that were responsive to Glu.

Ion channels activated directly by neurotransmitters also are present on astrocytes. This type of ion channel first was inferred to be present in cultured astrocytes in whole-cell patch-clamp studies (Sontheimer et al., 1988) and was subsequently demonstrated in cerebellar type-2 astrocytes in single-channel studies (Usowicz et al., 1989). The channel is activated by Glu and, like neuronal Glu channels, appears to be permeable to $\mathrm{Na}^{+}$and $\mathrm{K}^{+}$ions but not appreciably to $\mathrm{Ca}^{2+}$ (Sontheimer et al., 1988). However, it remains possible that a small $\mathrm{Ca}^{2+}$ permeability, coupled with a high receptor-channel density may allow these channels to mediate $\left[\mathrm{Ca}^{2+}\right]_{\mathrm{i}}$ rise. On the other hand, direct demonstration of Glu-activated channels has been demonstrated only in type- 2 astrocytes.

\section{Mechanisms for oscillations in $\left[\mathrm{Ca}^{2+}\right]_{i}$}

Two types of mechanisms could account for $\left[\mathrm{Ca}^{2+}\right]_{\mathrm{i}}$ oscillations induced by QA and Glu (Fig. $1 A, B$ ) in confluent astrocyte cultures. First, oscillation is an intrinsic property of single cells and the observed population response (about 6-10 cells in each recording field) represents synchronous cell oscillations; electrical coupling between astrocytes (Gutnick et al., 1981) may play a role in this synchrony. Agonist-induced oscillations in $\left[\mathrm{Ca}^{2+}\right]_{i}$ have been observed in a variety of nonexcitable cells and have been suggested to arise from feedback interactions between various factors: IP3-induced $\mathrm{Ca}^{2+}$ release, refilling of discharged pools, influx from the external medium (for review, see Rink and Jacob, 1988), and activation of protein kinase C (Nishizuka, 1986). While the present study cannot assess the relative contributions of these factors, $\mathrm{Ca}^{2+}$ influx appears to play an important role; in the absence of external $\mathrm{Ca}^{2+}$, Glu-induced $\left[\mathrm{Ca}^{2+}\right]_{\text {i }}$ responses scldom showed oscillations (Fig. $6 B$ ). Influx may provide just the amount of calcium ions needed, in addition to that released internally, to raise $\left[\mathrm{Ca}^{2+}\right]_{\text {i }}$ to a threshold level for oscillation. This influx also could be under negative-feedback reg- ulation by internal $\mathrm{Ca}^{2+}$; calcium rise activates the calciumactivated potassium channels present in astrocytes (Quandt and MacVicar, 1986), leading to membrane repolarization and closure of voltage-gated $\mathrm{Ca}^{2+}$ channels. This presumed reduction in $\mathrm{Ca}^{2+}$ influx further may underlie the damping of oscillations. Finally, protein kinase $C$ may down-regulate Glu receptors (Nishizuka, 1986; also see next section).

Second, studies have shown that neurotransmitters induce release of both excitatory (Glu) and inhibitory (GABA and taurine) amino acids from astrocytes (for review, see Schousboe et al., 1988). However, these studies were done under conditions in which glial cells were preloaded with labeled transmitters, and there is no published evidence that glial cells synthesize these transmittters. Conceivably, an oscillatory response initiated by Glu application could be reinforced by subsequent regenerative release of both excitatory and inhibitory amino acids from the astrocyte network. The gap junction channels coupling astrocytes may be permeable to second messengers like $\mathrm{Ca}^{2+}$ and IP3 (Saez et al., 1989), allowing intercellular signaling within a glial network. Indeed, propagating $\left[\mathrm{Ca}^{2+}\right]_{\mathrm{i}}$ waves have bccn observed in image analysis of cultured astrocytic network from rat hippocampus (Finkbeiner et al., 1989). Further, it remains possible that one reason why oscillations were not observed in the absence of external $\mathrm{Ca}^{2+}$ (Fig. 6) is that the 10-15 min of $\mathrm{Ca}^{2+}$-free preincubation used could have disrupted coupling between astrocytes which normally may be required for oscillatory, population $\left[\mathrm{Ca}^{2+}\right]_{\mathrm{i}}$ response.

\section{Role of protein kinase $C$}

One bifurcating limb of receptor-mediated hydrolysis of inositol lipids is the generation of diacylglycerol, which in turn activates a membrane-bound protein kinase $\mathrm{C}$. The observation here that Glu-induced rise in $\left[\mathrm{Ca}^{2+}\right]_{i}$ is inhibited by protein kinase $\mathrm{C}$ activation (Fig. 9), together with known Glu-mediated hydrolysis of inositol lipids in cultures astrocytes, suggests a negative-feedback mechanism which regulates the generation of second messengers (e.g., IP3, $\mathrm{Ca}^{2+}$ ). Indeed, flux measurements using ${ }^{45} \mathrm{Ca}^{2+}$ and biochemical studies of IP3 generation have shown that phorbol ester inhibits phosphoinositide hydrolysis and calcium mobilization in cultured astrocytoma cell lines (Orellana et al., 1985). It is possible that this negative-feedback inhibition only can be observed after protein kinase $C$ has been activated maximally by artificial means, as may be the case in the present study using phorbol esters. Whether physiological activation of protein kinase $\mathrm{C}$ during Glu exposure is sufficient for negativefeedback regulation of $\left[\mathrm{Ca}^{2+}\right]_{i}$ signaling to occur remains open.

An intriguing observation is that the Glu-induced $\left[\mathrm{Ca}^{2+}\right]_{\mathrm{i}}$ response was virtually abolished by phorbol ester treatment (Fig. 9). This suggests that not only the IP3 component but also the influx component of Glu-induced $\left[\mathrm{Ca}^{2+}\right]_{\mathrm{i}}$ response was inhibited by protein kinase $\mathrm{C}$ activation. One interesting possibility is that there is a coupling between protein kinase $\mathrm{C}$ and either the ion channels (voltage-gated $\mathrm{Ca}^{2+}$ channels, Glu-activated $\mathrm{Na} / \mathrm{K}$ channels) or the mechanism underlying Glu-induced depolarization. In this regard, it is noteworthy that the $\mathrm{KA}$ response, which consisted of a significant influx component, did not appear to be affected by phorbol ester (Fig. 9).

\section{Normal and abnormal physiological implications}

What are the physiological roles of excitatory amino acid-induced changes in $\left[\mathrm{Ca}^{2+}\right]_{\mathrm{i}}$ ? Most studies of neurotransmitter receptors in astrocytes have been performed in neuron-free, con- 
fluent cell cultures. Whether receptors are present on astrocytes in vivo remains to be resolved; comparatively, the various ion channel types first described for glial cells in culture have subsequently been demonstrated to be present in vivo (for review, see Barres et al., 1990). Indeed, recent electron microscopic immunocytochemical studies using a monoclonal antibody directed against $\mathrm{KA}$ receptors have revealed extensive immunoreactivity on Bergmann glial membranes adjacent to Purkinje fibers in cerebellar molecular layers (Eshhar et al., 1989).

Astrocytes not only outnumber neurons in the brain, but could function as a communicating network via extensive glia-to-glia coupling (Gutnick et al., 1981). A local response to Glu may give rise to propagating, frequency-coded $\left[\mathrm{Ca}^{2+}\right]_{i}$ signals (Fig. 2) which spread to other regions of an astrocytic syncytium, allowing a collective response (Finkbeiner et al., 1989). Rhythmic change in $\left[\mathrm{Ca}^{2+}\right]_{i}$, rather than a sustained one, may more effectively drive calcium-dependent enzymes in astrocyte physiology, like those involved in the glycogenolytic pathway (Ververken et al., 1982) or in neurotransmitter release (Schousboe et al., 1988). Furthermore, protein kinase $C$ activation may result in long-term cellular modulation like growth and differentiation (Nishizuka, 1986; Nicoletti et al., 1988). Finally, expression of $\mathrm{Ca}^{2+}$ channels in astrocytes has recently been found to be modulated by neurotransmitters (Tse and MacVicar, 1987; Barres et al., 1989); the ensuing $\mathrm{Ca}^{2+}$ influx modulation may lead to frequency modulation of oscillatory $\left[\mathrm{Ca}^{2+}\right]_{i}$ signaling.

Excessive exposure to Glu is toxic to neurons, which has been suggested to arise from agonist-induced $\mathrm{Ca}^{2+}$ overloading (for review, see Choi, 1988). Interestingly, Glu appears to be less toxic to glial cells; in neuron-glia cocultures, $0.5 \mathrm{~mm}$ Glu caused deaths of cortical neurons from fetal mouse but not the underlying astrocyte bed (Choi et al., 1987). However, in this study, the peak increase of $\sim 200 \mathrm{nM}$ in astrocyte $\left[\mathrm{Ca}^{2+}\right]_{\mathrm{i}}$ is similar to that of $\sim 250 \mathrm{nM}$ in mouse striatal neurons (Murphy et al., 1987) at the same Glu concentration $(100 \mu \mathrm{M})$. One reason for nontoxicity in glia may be that NMDA receptors are absent in astrocytes (Fig. 4); in neurons, NMDA receptor-activated channels have been suggested to be mediating $\mathrm{Ca}^{2+}$ influx in Glu toxicity (Choi, 1988). Another reason may be that the negativefeedback loop for $\left[\mathrm{Ca}^{2+}\right]_{i}$ regulation is set at a much higher gain in glia than neurons, allowing a quick damping of $\left[\mathrm{Ca}^{2+}\right]_{i}$ rise. Indeed, the damped $\left[\mathrm{Ca}^{2+}\right]_{\mathrm{i}}$ oscillation in astrocyte in response to Glu is very different from the nonoscillatory and more sustained rise seen in neurons (Murphy et al., 1987); any feedback system operating at high gain can easily generate oscillations, as is well known in voltage-clamp experiments in which currents show "ringing" when the amplifier gain is turned up too high. On the other hand, sympathetic neurons have been shown to exhibit cytosolic calcium oscillations in response to potassium depolarization and caffeine (for review, see Berridge and Galione, 1988).

Further, coupling between astrocytes via gap junctions may allow spatial buffering of $\left[\mathrm{Ca}^{2+}\right]_{i}$ in which an injurious level of $\left[\mathrm{Ca}^{2+}\right]_{i}$ is dissipated via gap junction channels to neighboring astrocytes. Indeed, recent evidence suggests that gap junction channels, at least in hepatocytes, are permeable to $\mathrm{Ca}^{2+}(\mathrm{Saez}$ et al., 1989). Propagating $\left[\mathrm{Ca}^{2+}\right]_{\mathrm{i}}$ waves induced by Glu in astrocyte networks in culture (Finkbeiner et al., 1989) may reflect dynamic spatial buffering of $\left[\mathrm{Ca}^{2+}\right]_{\mathrm{i}}$. Even though all cells are equally exposed in culture, there still may be a heterogenous $\left[\mathrm{Ca}^{2+}\right]_{i}$ response among individual cells which allows generation of an intercellular $\left[\mathrm{Ca}^{2+}\right]_{i}$ gradient. It should be noted that in- tercellular spatial buffering of calcium alone may not be sufficient to prevent toxicity, since many neurons in the hippocampus, for instance, also are coupled by gap junctions. Finally, calcium may not be involved in gliotoxicity; preliminary studies showed that the amino acid $\mathrm{L}-\alpha$-aminoadipic acid, which is toxic to astrocytes in culture (Cummings et al., 1988), was found to have no effect on astrocytic $\left[\mathrm{Ca}^{2+}\right]_{i}$ (tested at $0.1-1 \mathrm{~mm}, 3-6 \mathrm{~min}$ exposure). Taken together, these considerations suggest that $\mathrm{Ca}^{2+}$ in astrocytes is regulated (spatial buffering via gap junctions, feedback oscillations to code signals in frequency rather than amplitudes) to allow safe intracellular $\mathrm{Ca}^{2+}$ signaling without long-term danger of $\mathrm{Ca}^{2+}$-mediated cell injury.

\section{References}

Ahmed, Z., C. Lewis, and D. S. Faber (1989) Glutamate stimulates release of $\mathrm{Ca}$ from internal stores in astrocytes. Soc. Neurosci. Abstr. 15: 461.16 .

Barres, B. A., L. L. Y. Chun, and D. P. Corcy (1988) Ion channel expression by white matter glia: I. Type 2 astrocytes and oligodendrocytes. Glia $1:$ 10-30.

Barres, B. A., L. L. Y. Chun, and D. P. Corey (1989) Calcium current in cortical astrocytes: Induction by cAMP and neurotransmitters and permissive effect of serum factors. J. Neurosci. 9: 3169-3175.

Barres, B. A., L. L. Y. Chun, and D. P. Corey (1990) Ion channels in vertebrate glia. Annu. Rev. Neurosci. 13 (in press).

Berridge, M. J., and A. Galione (1988) Cytosolic calcium oscillators. FASEB 2: 3074-3082.

Bevan, S., S. Y. Chiu, P. T. A. Gray, and J. M. Ritchie (1985) The presence of voltage-gated sodium, potassium and chloride channels in rat cultured astrocytes. Proc. R. Soc. London [Biol.] 225: 299-313.

Black, J. A., and S. G. Waxman (1988) The perinodal astrocyte. Glia 1: $169-183$.

Bowman, C. L., and H. K. Kimelberg (1984) Excitatory amino acids directly depolarize rat brain astrocytes in primary culture. Nature 311: 656-659.

Choi, D. W. (1988) Calcium-mediated neurotoxicity: Relationship to specific channel types and role in ischemic damage. Trends Neurosci. 11: $465-469$.

Choi, D. W., M. Maulucci-Gedde, and A. R. Kriegstein (1987) Glutamate neurotoxicity in cortical cell culture. J. Neurosci. 7: 357-368.

Cummings, B. J., R. J. Bridges, A. Kundi, and C. W. Cotman (1988) Gliotoxic activity of acidic amino acids. Soc. Neurosci. Abstr. 14: 232.14.

Eshhar, N., J. D. B. Roberts, V. I. Teichberg, and P. Somogyi (1989) Localization of the cerebellar kainate receptors on Bergmann glial cells. Soc. Neurosci. Abstr. 15: 461.21 .

Finkbeiner, S. M., A. H. Cornell-Bell, M. S. Cooper, C. F. Stevens, and S. J. Smith (1989) Glutamate induces oscillating intracellular and propagating intercellular calcium waves in astrocytes. Soc. Neurosci. Abstr. 15: 461.19.

ffrench-Constant C., and M. C. Raff (1986) The oligodendrocyte-type2 astrocyte cell lineage is specialized for myelination. Nature 323 : 335-338.

Gallo, V., C. Giovannini, R. Suergiu, and G. Levi (1989) Expression of excitatory amino acid receptors by cerebellar cells of the type- 2 astrocyte lineage. J. Neurochem. 52: 1-9.

Grynkiewicz, G., M. Poenie, and R. Y. Tsien (1985) A new generation of $\mathrm{Ca}$ indicators with greatly improved fluorescence properties. J. Biol. Chem. 260: 3440-3450.

Gutnick, M. J., B. W. Connors, and B. R. Ransom (1981) Dye-coupling between glial cells in the guinea pig neocortical slice. Brain Res. 213: $486-492$.

Hille, B. (1975) Ionic selectivity of $\mathrm{Na}$ and $\mathrm{K}$ channels of nerve membranes. In Membranes $-A$ Series of Advances, Vol. 3, G. Eisenman, ed., pp. 255-323, Dekker, New York.

Inoue, I. (1981) Activation-inactivation of potassium channels and development of the potassium-channel spike in internally perfused squid giant axons. J. Gen. Physiol. 78: 43-61.

Jensen, A., and S. Y. Chiu (1989) Fluorescence measurement of changes in intracellular $\mathrm{Ca}$ induced by excitatory amino acids in cultured astrocytes. Soc. Neurosci. Abstr. 15: 461.18.

Kettenmann, H., K. H. Backus, and M. Schachner (1984) Aspartate, 
glutamate and $\gamma$-aminobutyric acid depolarize cultured astrocytes. Ncurosci. Lett. 52: 25-29.

Kettenmann, H., and M. Schachner (1985) Pharmacological properties of $\gamma$-aminobutyric acid-, glutamate-, and aspartate-induced depolarizations in cultured astrocytes. J. Neurosci. 5: 3295-3301.

Kuffler, S. W., J. G. Nicholls, and A. R. Martin (1984) Physiology of neuroglial cells. In From Neuron to Brain, pp. 323-360, Sinauer, Sunderland, MA.

Kuno, M., and P. Gardner (1987) Ion channels activated by inositol 1,4,5-triphosphate in plasma membrane of human $\mathrm{T}$-lymphocytes. Nature 326: 301-304.

Lazarewicz, J. W., and M. Kanje (1981) Effects of neurotransmitters on calcium efflux from cultured glioma cells. J. Neurosci. Res. 6: 283291.

Lieberman, E. M., N. J. Abbott, and S. Hassan (1989) Evidence that glutamate mediates axon-to-Schwann cell signaling in the squid. Glia 2: 94-102.

MacVicar, B. A. (1984) Voltage-dependent calcium channels in glial cells. Science 226: 1345-1347.

MacVicar, B. A., S. A. Crichton, D. M. Burnard, and F. W. Y. Tse (1987) Membrane oscillations in astrocytes induced by phorbol ester. Nature 329: 242-243.

Mayer, M. L., and G. L. Westbrook (1987) Permeating and block of $\mathrm{N}$-methyl-D-aspartic acid receptor channel by divalent cations in mouse central neurones. J. Physiol. (Lond.) 394: 501-527.

McCarthy, K. D., and J. De Vellis (1980) Preparation of separate astroglial and oligodendroglial cell cultures from rat cerebral tissue. J. Cell Biol. 85: 890-902.

Murphy, S. N., A. A. Thayer, and R. J. Miller (1987) The effects of excitatory amino acids on intraccllular calcium in single mouse striatal neurons in vitro. J. Neurosci. 7: 4145-4158.

Nicoletti, F., D. F. Condorelli, G. Magri, F. Ingrao, V. Bruno, M. V. Catania, and R. Avola (1988) Stimulation of inositol phospholipid hydrolysis by glutamate in glial cells: A possible role in the regulation of growth and differentiation. Soc. Neurosci. Abstr. 14: 421.5.

Nishizuka, Y. (1986) Studies and perceptives of protein kinase C. Science 233: 305-312.

Nowak, L. M., P. Bregestovski, P. Ascher, A. Herbert, and A. Prochiantz (1984) Magnesium gates glutamate activated channels in mouse central neurones. Nature 307: 462-465.

Orellana, S. A., P. A. Solski, and J. Heller Brown (1985) Phorbol ester inhibits phosphoinositide hydrolysis and calcium mobilization, in cultured astrocytoma cells. J. Biol. Chem 260: 5236-5239.

Pearce, B., and S. Murphy (1988) Neurotransmitter receptors coupled to inositol phospholipid turnover and $\mathrm{Ca}^{2+}$ flux: Consequences for astrocyte function. In Glial Cell Receptors, H. K. Kimelberg, ed., pp. 197-221, Raven, New York.

Quandt, F. N., and B. A. MacVicar (1986) Calcium activated potassium-channels in cultured astrocytes. Neuroscience 19: 29-41.

Raff, M. C. (1989) Glial cell diversification in the rat optic nerve. Science 243: 1450-1455.

Kink, I. J., and R. Jacob (1989) Calcium oscillations in non-excitable cells. Trends Neurosci. 12: 43-46.

Saez, J. C., J. A. Connor, D. C. Spray, and M. V. L. Bennett (1989) Hepatocyte gap junctions are permeable to the second messenger, inositol 1,4,5-triphosphate, and to calcium ions. Proc. Natl. Acad. Sci. IJSA 86: 2708-2712.

Schousboe, A., O. M. Larsson, P. Krogsgaard-Larsen, J. Drejer, and L. Hertz (1988) Uptake and release processes for neurotransmitter amino acids in astrocytes. In The Biochemical Pathology of Astrocytes, M. D. Norenberg, L. Hertz, and A. Schousboe, eds., pp. 381-394, Liss, New York.

Shain, W., J. A. Connor, V. Madelian, and D. L. Martin (1989) Spontaneous and beta-adrenergic receptor-mediated taurine release from astroglial cells are independent of manipulations of intracellular calcium. J. Neurosci. 9: 2306-2312.

Sontheimer, H., H. Kettenmann, K. H. Backus, and M. Schachner (1988) Glutamate opens $\mathrm{Na}^{+} / \mathrm{K}^{+}$channels in cultured astrocytes. Glia 1:328336.

Sugino, H., A. Ogura, Y. Kudo, and T. Amano (1984) Intracellular $\mathrm{Ca}^{2+}$ elevation hy a neurotransmitter in a glial cell clone. Brain Res. 322: $127-130$.

Tse, F. W., and B. A. MacVicar (1987) Isoproterenol enhances calcium current in cultured astrocytes. Soc. Neurosci. Abstr. 13: 330.12.

Tsien, R. Y. (1989) Fluorescent probes of cell signaling. Annu. Rev. Neurosci. 12: 227-253.

Usowicz, M. M., V. Gallo, and S. G. Cull-Candy (1989) Multiple conductance channels in type- 2 cerebellar astrocytes activated by excitatory amino acids. Nature $339: 380-383$.

Ververken, D., P. V. Van Veldhoven, C. Proost, H. Carton, and H. DeWulf (1982) On the role of calcium ions in the regulation of glycogenolysis in mouse brain cortical slices. J. Neurochem. 38: 12861295.

Vijendra, D., and K. D. McCarthy (1989) Type 2 astroglia exhibit a number of different neuroligand receptors that regulate intracellular calcium levels. Soc. Neurosci. Abstr. 15: 146.3.

Villegas, J. (1984) Axon-Schwann cell relationship. Curr. Trop. Memb. Transport 22: 547-571. 